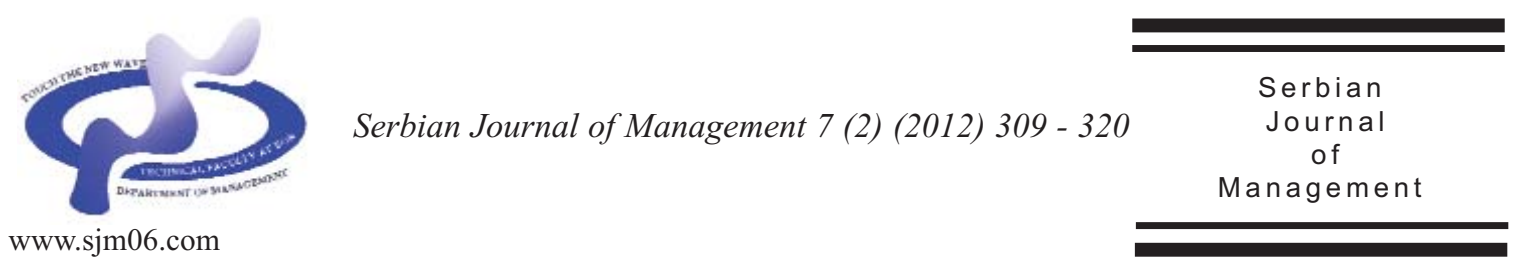

\title{
BUSINESS STRATEGIES IN UNSTABLE INSTITUTIONAL ENVIRONMENT - CASE OF BRIC COUNTRIES
}

\author{
Branko Rakita, Dragan Azdejković and Dušan Marković* \\ University of Belgrade, Faculty of Economics, \\ Kamenička 6, 11000 Belgrade, Serbia
}

(Received 17 May 2012; accepted 7 October 2012)

\begin{abstract}
The visionary idea of $\mathrm{BRIC}^{1}$ countries and their leading position in the development of global economy, conceived by the leading investment bank Goldman Sachs more than a decade ago, came under heavy skepticism. However, what many doubted came true. At the end of 2011 BRIC countries generated approximately $26 \%$ of global GDP, and their share in the growth of global GDP was more than $50 \%$. The impressive growth of BRIC countries has been in large measure due to FDI inflow 2 . Intensive FDI inflow and economic development have not been followed by improved institutional efficiency. This article will show that inefficient institutions in BRIC countries have not been discouraging to $\mathrm{MNCs}^{3}$, who were predominantly led by the extent and the growth dynamics of the market. Modifications to business strategies applied in developed countries by MNCs, in order to manage unstable institutional environment in BRIC countries, will be analyzed. The conclusion is that the key modification is establishment of strong relationships with local stakeholders, in order for MNCs to gain necessary knowledge of the new business environment and create a sound basis for institutional efficiency improvement.
\end{abstract}

Keywords: BRIC countries, FDI, institutions, business strategy

\section{INTRODUCTION}

Vast technological, socio-political and economic changes have occurred from the beginning of the $21^{\text {st }}$ century and created a

* Corresponding author:dusanm@ekof.bg.ac.rs

DOI: $10.5937 /$ sjm 7-2681 new business environment. The most prominent characteristic of the new environment is that fast growing BRIC markets opened up to MNCs from developed countries. Within only a decade, from 2001

\footnotetext{
${ }^{1}$ Brazil, Russia, India and China

${ }^{2}$ Foreign Direct Investments

${ }^{3}$ Multinational Companies
} 
to 2011, BRIC countries increased their GDP by purchase power parity (PPP) from USD 7,361 billion to USD 20,955 billion, and calculated cumulative growth of $185 \%$. At the end of 2011 BRIC countries generated $26 \%$ of global GDP at PPP, and more importantly, their contribution to global GDP growth was more than 50\% (www.cia.gov and databank.worldbank.org). Compared with developed economies, BRIC countries have been less severely hit by global economic crisis, which accelerated shift of economic power from G7 to BRIC countries.

Fast economic growth of BRIC countries has primarily been a consequence of strong inflow of FDIs, which has dominantly been determined by the potential and growth dynamics of BRIC markets. Between 2001 and 2010 population in these countries increased from 2.67 to 2.91 billion which accounted for more than $42 \%$ of the world's population (databank.worldbank.org). Due to GDP and population growth BRIC countries have become one of the key players in global demand. In 2009 these countries' share in the growth of global demand was more than a half, and China comprised over $30 \%$ of global demand growth, almost twice as much as the USA (Tetsufumi et al., 2009).

BRIC countries liberalized FDI regulations alongside their economic development, and created new business opportunities for MNCs from developed countries. MNCs have been facing up to various business risks, mainly undeveloped infrastructure, inefficient formal and specific informal institutions. Nevertheless, MNCs have not been deterred by the risks, and have gradually learned how to adjust their business strategies and influence institutions in the host countries through the network of local contacts.
This paper consists of three parts. The first part of the article, with reference to relevant literature, explains how institutional environment influences business strategies, specially emphasizing so called emerging economies. Research hypotheses is founded on institution based view, and tested in the second and the third part of the article. The second part of the paper gives econometric model which should specify the influence of institutional and market determinants on FDI inflow in BRIC countries. The model analyzes two market and two institutional determinants from 1996 to 2010. The third part of the paper gives a detailed explanation of MNCs' strategic response to unstable institutional environment in BRIC countries. A great deal of stress is put on the importance of local strategic networks made of numerous stakeholders through which MNCs collect necessary information and knowledge of local business environment and thus influence it.

\section{THE INFLUENCE OF INSTITUTIONAL ENVIRONMENT ON INTERNATIONAL BUSINESS STRATEGIES}

Rapid development and growing importance of BRIC countries have been standing out on the global economic map in the past decade. Two leading views defining the factors of companies' competitive advantage were brought into question due to strong development of institutionally inefficient countries.

Industry based view, established more than thirty years ago, derives five forces (barging power of buyers, barging power of suppliers, intensity of competitive rivalry, threat of new competition, threat of 
substitute products or services) within an industry that determine business strategy and performances of a company (Porter, 2008). On the other hand, resource based view, established more than two decades ago, points out that the basis for a competitive advantage of a company lies in application of valuable, rare, imperfectly imitable, and nonsubstitutable resources (Barney, 1991). These two views take the structure of an industry and unique resources as a basis of competitive advantage, disregarding the whole business context. Since the institutional systems in emerging economies differ widely from those in developed countries, formal and informal institutions have been recognized as a determinant of business strategy and company's performance. This led to the institution based view which modifies industry based view and resource based view. Figure 1 shows the relationship between the three views.
Competitive advantage of a company can be determined by the resources it owns. It can be determined by location, transferability and non-transferability of resources, as well. Yet, the mere possession of resources does not create competitive advantage. A company must exploit them efficiently and adequately combine them (Verbeke, 2009). Transferable resources can be moved abroad and thus strengthen competitive advantage of a company in a foreign market, though resources producing advantage in one institutional context can behave differently in another.

Institutional context is not just a background condition but the one directly determining the aces company has up its sleeve when formulating and implementing strategy and creating competitive advantage (Peng et al., 2008). Therefore, institutions directly determine internationalization strategies and performances of a company

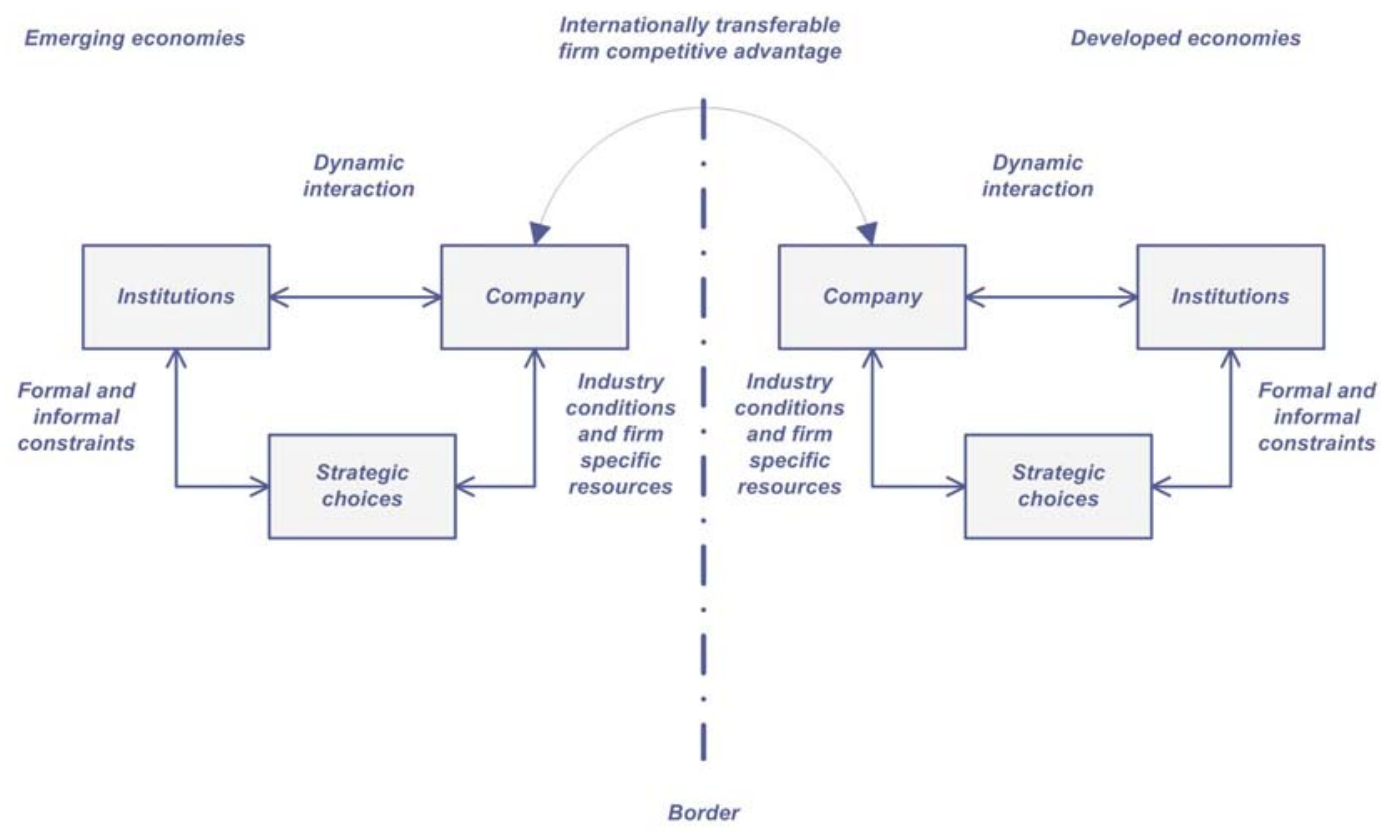

Figure 1. Relationship between the three views of competitive advantage and international business (Adjusted according to Peng, et al, 2009) 
for several reasons: 1. efficiency of institutions affects productivity prospects 2 . poor institutions can bring additional costs and 3. due to high sunk costs companies are vulnerable to any kind of uncertainty (Benassy et al., 2007).

Institutions should define the norms and framework for doing business and thus decrease the uncertainty. Stakeholders on the other hand make rational decisions obeying formal and informal rules of the business environment (Peng \& Khoury, 2008). MNCs from developed countries often disregard this fact and tend to imitate strategies that proved successful in domestic markets. Abandoned business models, once used in highly developed countries with efficient institutions, actually proved to be very successful in emerging markets because companies take over some of the functions of undeveloped and inefficient institutions (Khanna \& Palepu, 1997). Stakeholders tend to develop business models that would decrease the uncertainty stemming from inefficient governments. If a government functions poorly and vaguely, informal institutions take over some of its duties and help companies make decisions and thus decrease uncertainty (Peng et al., 2009). MNCs from developed countries have no experience in doing business in unstable institutional environment and are not accustomed to informal institutions, and therefore must obtain local knowledge and resources.

Two related hypotheses set up in this paper are founded on institution based view:

H1: FDI inflow in BRIC countries has dominantly been influenced by market determinants and the influence of the institutions was negligible.
H2: MNCs tend to overcome the problem of poor institutions in BRIC countries by intensifying the cooperation with local stakeholders.

\section{ECONOMETRIC ANALYSIS OF FDI INFLOW DETERMINANTS IN BRIC COUNTRIES}

Determinants of FDI inflow have been analyzed in economic literature a lot. Most of the empirical research conducted tried to identify economic or institutional determinants of FDI inflow. The basic assumption in this paper is that FDI inflow is determined both by economic and institutional determinants.

Vector autoregressive model (VAR) was used in the analysis. The starting assumption of this approach is that most of macroeconomic time series are timedependent (Jovičić \& Dragutinović, 2011, Mladenović \& Nojković, 2012, Stata Corp LP, 2011). This requires a model that allows dynamic analysis of the relationship between the variables. From Sims' pioneer work (Sims, 1980) until today this has been one of the most commonly used concepts in economic research (see for example Mladenović \& Nojković, 2012 and Stata Corp LP, 2011).

In this model $K$ variables are a linear function of $p$ their past evolutions, of $p$ past evolutions of $K-1$ variables and possibly of some additional exogenous variables. Formula 1 gives the algebraic form of $p$-lag vector autoregressive model, or $\operatorname{VAR}(p)$, with exogenous variable $x_{t}$ :

$$
\begin{aligned}
& y_{t}=c+A_{1} y_{t-1}+A_{2} y_{t-2}+\ldots+A_{p} y_{t-p}+B_{0} x_{t}+ \\
& B_{1} x_{t-1}+\ldots+B_{s} x_{t-s}+u_{t} \quad t \in\{-\infty,+\infty\}
\end{aligned}
$$


$y_{t}=\left(y_{1}, y_{2}, \ldots, y_{k t}\right)^{\prime}$ is $K \times 1$ random (stochastic) vector,

$A_{1}$ to $A_{p}$ are $K \times K$, parameter matrices, $x_{t}$ is $M \times$, exogenous variables vector,

$B_{0}$ to $B_{s}$ are $K \times M$, coefficient matrices, $c$ is $K \times 1$, parameters vector, and

$u_{t}$ is white noise vector process; i.e. $E\left(u_{t}\right)=0, E\left(u_{t}, u_{t}^{\prime}\right)=\sigma$ and $E\left(u_{t}, u_{s}^{\prime}\right)=0$ for $t \neq s$.

Two economic and two institutional determinants were analyzed for each of BRIC countries. Economic determinants used in the model are: FDI inflow in the previous year (i) in millions USD and consumption (c) in billions USD. The source of the data on FDI is UNCTAD database, and of the data on consumption is the World Bank database. Two of six governance indicators published by the World Bank in the World Governance Indicators were used in the model as institutional determinants. This report has been measuring the quality of institutions in 213 countries since 1996. Government effectiveness $\left(\mathrm{k}_{1}\right)^{4}$ and control of corruption $\left(\mathrm{k}_{2}\right)^{5}$ were analyzed, since the two are the best indicators of institutional environment of a country. The indicators are measured in units ranging from -2.5 to 2.5 , with higher values corresponding to more efficient institutions. Time series between 1996 and 2010 were analyzed and the arithmetic mean of two consecutive years were used to approximate the missing data on 1997, 1999 and 2001. Table 1 and table 2 show the data used as inputs in the analysis. $c$ - Consumption in billion USD (databank.worldbank.org).

$i \quad-$ FDI in million USD (unctadstat.unctad.org).

$k_{1}$ - Government effectiveness indicator, $\begin{array}{llll}\text { ranging from } & -2.5 \text { to } & 2.5\end{array}$ (http://info.worldbank.org).

$k_{2}$ - Control of corruption indicator, ranging from -2.5 do 2.5 (http://info.worldbank.org).

Statistical software package STATA 12 (Stata Corp LP, 2011), or more precisely its sub module for VAR models, was used. Var, varstable, varsoc and vargranger ${ }^{6}$ commands show that the problem fits the model that can be expressed with equations from 2 to 5 :

Table 1. The data used in the econometric model (Brazil and Russia)

\begin{tabular}{|c|c|c|c|c|c|c|c|c|}
\hline & \multicolumn{5}{|c|}{ Brazil } & \multicolumn{5}{c|}{ Russia } \\
\hline & $\boldsymbol{c}$ & $\boldsymbol{i}$ & $\boldsymbol{k} \boldsymbol{k} 2$ & $\boldsymbol{c}$ & $\boldsymbol{i}$ & $\boldsymbol{k} \boldsymbol{I}$ & $\boldsymbol{k} \mathbf{2}$ \\
\hline 1996 & 542.967 & 10.792 & $-0,15$ & $-0,07$ & 203.782 & 2.579 & $-0,55$ & $-1,03$ \\
\hline 1997 & 565.210 & 18.993 & $-0,14$ & $-0,04$ & 221.677 & 4.865 & $-0,65$ & $-0,98$ \\
\hline 1998 & 542.855 & 28.856 & $-0,13$ & 0,00 & 155.714 & 2.761 & $-0,76$ & $-0,94$ \\
\hline 1999 & 379.878 & 28.578 & $-0,05$ & 0,02 & 104.894 & 3.309 & $-0,72$ & $-0,95$ \\
\hline 2000 & 414.835 & 32.779 & 0,04 & 0,04 & 119.954 & 2.714 & $-0,68$ & $-0,95$ \\
\hline 2001 & 351.359 & 22.457 & 0,04 & 0,03 & 151.419 & 2.748 & $-0,52$ & $-0,94$ \\
\hline 2002 & 311.187 & 16.590 & 0,05 & 0,01 & 176.768 & 3.461 & $-0,35$ & $-0,92$ \\
\hline 2003 & 342.138 & 10.144 & 0,19 & 0,11 & 218.047 & 7.958 & $-0,38$ & $-0,71$ \\
\hline 2004 & 396.790 & 18.146 & 0,04 & 0,03 & 298.094 & 15.444 & $-0,37$ & $-0,74$ \\
\hline 2005 & 531.730 & 15.066 & $-0,09$ & $-0,17$ & 381.556 & 12.886 & $-0,46$ & $-0,79$ \\
\hline 2006 & 647.032 & 18.822 & $-0,13$ & $-0,14$ & 482.855 & 29.701 & $-0,49$ & $-0,84$ \\
\hline 2007 & 801.264 & 34.585 & $-0,10$ & $-0,11$ & 633.975 & 55.073 & $-0,43$ & $-0,95$ \\
\hline 2008 & 964.836 & 45.058 & 0,00 & $-0,02$ & 812.123 & 75.002 & $-0,37$ & $-1,04$ \\
\hline 2009 & 967.400 & 25.949 & 0,02 & $-0,10$ & 667.823 & 36.500 & $-0,34$ & $-1,12$ \\
\hline 2010 & 1.216 .130 & 48.438 & 0,07 & 0,06 & 768.177 & 41.194 & $-0,39$ & $-1,07$ \\
\hline
\end{tabular}

\footnotetext{
${ }^{4}$ The quality of public services, the independence of the civil service from political pressures, the quality of policy formulation and implementation, and the government's commitment to its stated policies.

${ }^{5}$ Corruption is defined as the extent to which power is used for private gain.

${ }^{6}$ The data and detailed analysis is available on http://one.ekof.bg.ac.rs/ azdr/bor.rar
} 
Table 2. The data used in the econometric model (India and China)

\begin{tabular}{|c|c|c|c|c|c|c|c|c|}
\hline & \multicolumn{5}{|c|}{ India } & \multicolumn{5}{c|}{ China } \\
\hline & $\boldsymbol{c}$ & $\boldsymbol{i}$ & $\boldsymbol{k} \boldsymbol{k}$ & $\boldsymbol{k}$ & $\boldsymbol{c}$ & $\boldsymbol{i}$ & $\boldsymbol{k} \boldsymbol{~}$ & $\boldsymbol{k} 2$ \\
\hline 1996 & 255.120 & 2.525 & $-0,10$ & $-0,41$ & 408.408 & 41.726 & $-0,30$ & $-0,25$ \\
\hline 1997 & 264.030 & 3.619 & $-0,08$ & $-0,35$ & 445.385 & 45.257 & $-0,22$ & $-0,25$ \\
\hline 1998 & 268.647 & 2.633 & $-0,06$ & $-0,29$ & 473.835 & 45.463 & $-0,14$ & $-0,25$ \\
\hline 1999 & 290.206 & 2.168 & $-0,08$ & $-0,33$ & 506.389 & 40.319 & $-0,11$ & $-0,25$ \\
\hline 2000 & 294.539 & 3.588 & $-0,10$ & $-0,37$ & 553.907 & 40.715 & $-0,09$ & $-0,24$ \\
\hline 2001 & 308.292 & 5.478 & $-0,12$ & $-0,43$ & 597.263 & 46.878 & $-0,07$ & $-0,45$ \\
\hline 2002 & 320.820 & 5.630 & $-0,15$ & $-0,49$ & 641.016 & 52.743 & $-0,05$ & $-0,65$ \\
\hline 2003 & 370.726 & 4.321 & $-0,07$ & $-0,43$ & 696.503 & 53.505 & $-0,10$ & $-0,43$ \\
\hline 2004 & 426.753 & 5.778 & $-0,13$ & $-0,42$ & 787.968 & 60.630 & $-0,05$ & $-0,57$ \\
\hline 2005 & 486.216 & 7.622 & $-0,08$ & $-0,40$ & 886.622 & 72.406 & $-0,17$ & $-0,64$ \\
\hline 2006 & 548.688 & 20.328 & $-0,01$ & $-0,28$ & 1.029 .718 & 72.715 & 0,06 & $-0,50$ \\
\hline 2007 & 707.724 & 25.350 & 0,12 & $-0,42$ & 1.256 .783 & 83.521 & 0,23 & $-0,59$ \\
\hline 2008 & 709.606 & 42.546 & $-0,02$ & $-0,40$ & 1.592 .410 & 108.312 & 0,19 & $-0,44$ \\
\hline 2009 & 795.209 & 35.649 & $-0,02$ & $-0,37$ & 1.773 .498 & 95.000 & 0,14 & $-0,50$ \\
\hline 2010 & 987.494 & 24.640 & $-0,01$ & $-0,52$ & 1.968 .992 & 105.735 & 0,12 & $-0,60$ \\
\hline
\end{tabular}

Brazil:

$\log i_{t}=0.21 \log i_{t-1}+0.71 \log c_{t-1}-0.03$ $k_{1}+0.01 k_{2} \quad\left(\mathrm{R}^{2}=0.60\right)$

India:

$\log i_{t}=0.15 \log i_{t-1}+1.80 \log c_{t-1}+0.07$ $k_{1}-0.04 k_{2} \quad\left(\mathrm{R}^{2}=0.92\right)$

China:

$\log i_{t}=0.31 \log i_{t-1}+0.41 \log c_{t-1}-0.04$ $k_{1}+0.01 k_{2} \quad\left(\mathrm{R}^{2}=0.94\right)$

Russia:

$\log i_{t}=0.31 \log i_{t-1}+1.04 \log c_{t-1}+0.05$ $k_{1}+0.10 k_{2} \quad\left(\mathrm{R}^{2}=0.91\right)$

( $\log$ stands for logarithmic form)

Exceedingly high values of $\mathrm{R}^{2}$, with slight exception of Brazil, show that these four variables explain the FDI inflow over the current period, to a great extent. There is a slight difference in the results of the analysis among the countries, and consumption stands out as the most important determinant. China does not entirely follow the pattern, due to export oriented economy and government measures taken in the previous period to control domestic demand and inflation. And finally, compared to institutional variables, economic variables have significantly more influence on FDI inflow, with the exception of Russia, known as a highly corrupted country, where corruption indicator value is slightly higher. Though being short, the time series proves the hypothesis $H 1$, with small differences among the analyzed countries. The influence of institutional environment on FDI inflow in BRIC countries was insignificant. Foreign investors dominantly gave an advantage to the market potential, and market and marketing prospects, over unstable and undeveloped institutions in these countries.

\section{PARTNERSHIP WITH LOCAL STAKEHOLDERS AS AN UNDEVELOPED INSTITUTIONAL ENVIRONMENT MANAGEMENT} TOOL

In order to achieve economy of scale based on possession of unique resources, or to make use of a foreign location as their 
competitive advantage, companies internationalize their business. Nevertheless, besides possible economic benefits companies should not disregard additional coordination costs of the resource exploitation in foreign markets. There are three possible options for foreign investors: 1. to disregard institutionally unstable markets, 2. to adapt to new business environment trying to persevere in applying the strategy which had proved to create competitive advantage, 3 . to actively influence new business environment (Khanna et al., 2005). Strategy of late followers, or "wait and see", is not acceptable to most of the companies due to the fact that institutions in BRIC countries are not likely to advance to the level their counterparts in developed countries are on in near future, and the importance of BRIC economy on the global level will certainly keep growing.

Since the above passages prove that inefficient institutions did not discourage MNCs to invest in BRIC countries, the conclusion is that foreign investors have been entering these markets by adjusting to the new environment, simultaneously tending to improve it. This is a very complex process influenced by a wide variety of factors. Entry strategy is a highly significant factor contributing to company's ability to adapt to the new business environment.

MNCs see investments in BRIC countries as means of exploiting complementary local resources alongside the resources already in their possession. Local resources can be basic and strategic. Basic resources are mainly material resources (equipment, cheap labor, natural resources etc.) and are available through market transactions. Strategic resources are mostly intangible resources (strong reputation, brand strength and value, negotiation power, intellectual capital, knowledge workers, political contacts, familiarity with local markets etc.) that cannot be easily or completely obtained in free market, and cannot be easily substituted or imitated by competition. These resources can be internally generated, or acquired through partnerships or acquisitions of local companies (Barney \& Tong, 2006; Stefanovic et al., 2011). MNCs cannot easily generate intangible local resources, especially if they lack necessary experience. Therefore, business strategies based on these resources must be implemented through acquisitions of or strategic alliances with local companies. Relatively undeveloped and inefficient institutions are a great obstacle to the acquisitions. Financial markets are mostly inefficient and illiquid since local companies are usually controlled by influential individuals or families, and financial and other business data on companies is incomplete and unreliable (Meyer et al., 2009). Consequently, the resources of target company cannot be properly identified and valued, and acquisition costs increase. In order to obtain local strategic resources, necessary for doing business in unstable business environment, most of MNCs give advantage to strategic alliances over international acquisitions (Chen et al., 2004). This allows them utilize local strategic resources, share possible business risks and learn how to do business in a complex institutional environment.

Strategic partnerships in BRIC countries must be analyzed within the context of undeveloped institutions. Domestic companies in emerging economies have built a network of personal contacts, as a compensation for inexistence or inefficiency of official institutions (Hoskisson et al., 2000). This network represents informal 
institutions which act as a substitute for formal institutions. Network members are not strong enough to compete on their own, and use networking to position themselves in the market (Hitt et al., 2004). Local network of personal contacts is a great barrier to foreign companies on their way to new markets. Nevertheless, companies within the network need intangible resources as a source of long-term competitive advantage, technology and management knowledge, and only MNCs are the proper partner that can provide them with these (Hitt et al., 2006). Therefore, MNCs swap their intangible resources for membership in the local network and thus exploit informal institutions developed by local companies and collect the data on local business environment. Local partners should possess complementary resources and should not misuse the access to intangible resources (technology, strong reputation, brand etc.), and for that reason MNCs must be very careful when engaging in partnerships with local companies. This is of crucial importance since most often formal institutions are not willing or lack the capacity to protect intellectual property. Relations within a network are based on personal contacts, the leaders negotiate the goals and the outcome is usually uncertain (Puffer \& McCarthy, 2007). Due to high uncertainty and unofficial decision making practice, it is in MNCs' best interest to encourage the development of the missing formal institutions and increase the efficiency of the existing ones.

MNCs influence institutional environment in its host countries over time, and there are three avenues through which this can be performed: professionalization effect, demonstration effect, and regulatory pressure effect (Kwok \& Tadesse, 2006).
Professionalization effect and demonstration effect are extremely indirect and hard to measure. There is a huge discrepancy between the business standards set in MNCs and their affiliates, and the local business practice (for example corrupt practices). Employee fluctuation and demonstration effect increase the number of local companies adopting the new standards, which pressures institutions to advance their efficiency.

MNCs draw local stakeholders into a network which can but does not necessary have to be based on the contacts of local strategic partner, and thus directly influence institutional environment (Iankova \& Katz, 2003). There are high-intensity and lowintensity networks, depending on to what degree institutional inefficiency affects MNCs. Through low-intensity networks MNCs join their efforts to lobby governments and share lobbying costs, without drawing too much attention to themselves. The network is comprised of both local strategic partner and MNCs' affiliates (Foreign Investors Council in Serbia). Nevertheless, low-intensity networks work only at national level and deal with general problems of institutional environment. On the other hand, highintensity networks are comprised of various stakeholders (trade unions, municipalities, suppliers etc.) and affect specific institutional problems with the aim of improving it. Strategic partner's local knowledge, and his political and contacts with other stakeholders are crucial to this strategy. MNCs affect institutional environment long lastingly and continuously, and the outcome is often hard to measure.

Company should not disregard time dimension and long-term perspective when deciding the optimal entry strategies. 
Nevertheless, final choice of the entry strategies is not once and for all process. They should be revised, adjusted, and developed over time, since economic and institutional environment, and company's development priorities and capacities, are in constant change. Foreign investors gain the necessary experience and acquire local resources over time, and being able to perform independently they usually abandon strategic partnerships or set the limits to strategic partnership business activities. Once exclusive strategic partnership is now in charge of a few segments, and MNC gets the biggest piece of the pie, and continues performing autonomously. This way, MNCs do not entirely abandon local partnership as valuable source of local resources and still they can do business independently. Besides, ties with successful local companies do not leave the room for late followers to easily obtain local knowledge and resources crucial for doing business in BRIC markets.

\section{CONCLUSIONS}

Shift of economic power from G7 to BRIC countries is among the most significant processes of today. Intensive economic growth and development in BRIC countries have not been followed by increasing institutional efficiency. Therefore, the two leading views, industry and resource based view, defining the determinants of competitive advantage in institutionally developed countries, were not applicable in the new business environment. This led to institution based view which modifies industry based view and resource based view in order to identify the source of companies' competitive advantage. It points out that MNCs must adjust their business strategies and develop new sources of competitive advantage, depending on the level of institutional efficiency.

The results of the research on business strategies implemented in BRIC countries are conformable to institution based view. The econometric model applied in the research analyzed consumption, FDI inflow in the previous year, government effectiveness and control of corruption. The model explains over $90 \%$ of variations of FDI in the analyzed countries, with the exception of Brazil where the result was $60 \%$. As it was assumed, FDI inflow was dominantly determined by consumption and to a smaller degree by FDI inflow in the previous year, while the influence of the institutional determinants was less significant. This proves the hypothesis $H 1$, that FDI inflow in BRIC countries has dominantly been influenced by market determinants (consumption and future market growth rates) and the influence of the institutions is negligible.

In order to exploit growing market opportunities and successfully manage the risks stemming from unstable institutional environment, most of the MNCs enter BRIC markets in the form of strategic partnerships with local companies. Through local strategic networks and partnerships MNCs collect necessary information and knowledge of the local business environment and modify their business strategies accordingly. Additionally, local strategic partnerships are often the basis for MNCs' networking, with the aim of directing the development of institutional environment towards desired goals. MNCs thus become the agent of change with the task to advance the entire business environment.

Serbian companies operating internationally could make practical use of 
this research. Due to falling demand and sharp competition in developed markets, especially EU markets, it has become much harder to operate there. Therefore, Serbian companies going international tend to make a breakthrough into emerging markets, including BRIC countries. However, on their way to these new markets they must bear in mind the importance of informal institutions and specific institutional environment that significantly differ from what they are used to in Serbia and EU countries. Successful performance in BRIC markets will depend on their ability to acquire strategic local resources that are essential for doing business in this specific environment. Nevertheless, acquisition of these resources depends on company's ability to establish relationships with relevant local stakeholders and thus become a member of their personal networks which allow them influence formal institutions and substitute for inefficient formal institutions.

\title{
СТРАТЕГИЈЕ ПОСЛОВАЫА У НЕСТАБИЛНОМ ИНСТИТУЦИОНАЛНОМ АМБИЈЕНТУ - ПРИМЕР БРИК ЗЕМАЉА -
}

\author{
Бранко Ракита, Драган Аздејковић и Душан Марковић
}

\section{Извод}

Када је пре више од једне деценије водећа инвестициона банка Goldman Sachs осмислила акроним БРИК ${ }^{1}$ и предвидела да ће ове земље имати водећу улогу у развоју глобалне економије многи су били скептични. Оно у шта су многи сумњали остварило се. На крају 2011. године БРИК земље су генерисале скоро $26 \%$ глобалног ГДП, али је много битније да су допринеле расту глобалног ГДП са преко 50\%. Импресиван раст БРИК земаља у претходном периоду у великој је мери последица снажног прилива СДИ². Снажан економски развој у претходном периоду није био праћен унапређењем ефикасности институција. У раду ће бити показано да релативно неефикасне институције у БРИК земљама нису деловале одбијајуће на МНК, ${ }^{3}$ које су се доминантно водиле величином и динамиком развоја тржишта. Анализираће се модификације пословних стратегија МНК, у односу на примењиване на тржиштима развијених земаља, а чија је сврха управљање нестабилним институционалним амбијентом. Закључак је да се модификовање пословних стратегија огледа у успостављању снажних веза са локалним стејкхолдерима, а све у циљу стицања неопходних знања за пословање у специфичном пословном амбијенту и креирању базе путем које би се утицало на подизање ефикасности институција.

Кључне речи: БРИК земље, СДИ, институције, пословна стратегија

\footnotetext{
${ }_{1}$ Бразил, Русија, Индија и Кина

${ }^{2}$ Стране директне инвестиције

${ }^{3}$ Мултинационалне компаније
} 


\section{References}

Barney, J. (1991). Firm Resources and Sustained Competitive Advantage. Journal of Management, 17(1): 99-120.

Barney, J., \& Tong, W.T. (2006). Building versus Acquiring Resources. Pp. 57-81 in A. Ghobadian, N. O'Regan, D. Galler \& H. Viney (editors), Strategy and Performance Achieving Competitive Advantage in the Global Marketplace, London, UK, Middlesex University Business School.

Benassy, Q.A., Maylis, C., \& Thierry, M. (2007). Institutional Determinants of Foreign Direct Investment. The World Economy, 30(5): 764-782.

Chen, T-J., Chen, H., \& Ku, Y-H. (2004). Foreign Direct Investments and Local Linkages. Journal of International Business Studies, 35(4): 320-333.

Hitt, M.A., Ahlstrom, D., Dacin, M.T., Levitas, E., \& Svobodina, L. (2004). The Institutional Effects on Strategic Alliance Partner Selection in Transition Economics: China vs Russia. Organization Science, 15(2): 173-185.

Hitt, M., Ireland, D., \& Santoro, M. (2006). Developing and Managing Strategic Alliances, Building Social Capital and Creating Value. Pp. 13-34 in A. Ghobadian, N. O'Regan, D. Galler \& H. Viney (editors), Strategy and Performance Achieving Competitive Advantage in the Global Marketplace, London, UK, Middlesex University Business School.

Hoskisson, R.E., Eden, L., Lau, C.M., \& Wright, M. (2000). Strategy in Emerging Economies. Academy of Management Journal, 43(3): 249-267.

Iankova, E., \& Katz, J. (2003). Strategies for Political Risk Mediation by International Firms in Transition Economies: The Case of Bulgaria, Journal of World Business. 38(3):
182-203.

Jovičić, M., \& Dragutinović, M.R. (2011). Econometrics methods and models. Belgrade, Serbia, Faculty of Economics. (In Serbian)

Khanna, T., \& Palepu, G.K. (1997). Why Focused Strategies May be Wrong for Emerging Markets. Harvard Business Review, 75(4): 41-51.

Khanna, T., Palepu, G.K., \& Sinha J. (2005). Strategies That Fit Emerging Markets. Harvard Business Review, 83(6): 63-77.

Kwok, C.C.Y., \& Tadesse, S.A. (2006). The MNC as an Agent of Change for HostCountry Institutions: FDI and Corruption. Journal of International Business Studies, 37(6): 767-785.

Meyer, K.E., Estrin, S., Bhaumik, S.K., \& Peng. M.W. (2009). Institutions, Resources and Entry Strategies in Emerging Economies. Strategic Management Journal, 30(1): 61-80.

Mladenović, Z., \& Nojković, A. (2012). Applied Time Series Analysis. Belgrade, Serbia, Faculty of Economics. (In Serbian)

Peng, W.M., \& Khoury, T. (2008). Unbundling the Institution Base View of International Business Strategy. In Pp. 256268 A. M. Rugman (editor), The Oxford Handbook of International Business, NY, USA, Oxford University Press.

Peng, W.M., Sunny, L.S., Pinkham, B., \& Chen, H. (2009). The Institution-Based View as a Third Leg for a Strategy Tripod. Academy of Management Perspective, 23(3): 63-81.

Peng, W.M., Wang, D.Y.L., \& Jiang, Y. (2008). An Institution-Based View of International Business Strategy: A Focus on Emerging Economies. Journal of International Business Studies, 39(5): 920936. 
Porter, E.M. (2008). The Five Competitive Forces That Shape Strategy. Harvard Business Review, 86(1): 79-93.

Puffer, S., \& McCarthy, D. (2007). Can Russia's State Managed, Network Capitalism be Competitive? Institution Pull versus Institution Push. Journal of World Business, 42(1): 1-13.

Sims, A.C. (1980). Macroeconomics and Reality. Econometrica, 48(1): 1-48.

Stata Corp LP. (2011). Time-Series Reference Manual. College Station, Texas, USA Stata Press.

Stefanović, I., Ranković, Lj., Prokić, S. (2011). Entrepreneurs Motivational Factors: Empirical Evidence from Serbia. Serbian Journal of Management, 6(1): 73-83.

Tetsufumi, Y., Swarnali, A., \& Kelston, A. (2009). The BRICs as Driver of Global Consumpiton. Goldman Sachs Global Economics Paper, 09(07): 1-4.

Verbeke, A. (2009). International Business Strategy. NY, USA, Cambridge University Press.

On line references:

www.cia.gov/library/publications/theworld-factbook/geos/xx.html

http://databank.worldbank.org/ddp/home. do

http://unctadstat.unctad.org/ReportFolder s/reportFolders.aspx

http://info.worldbank.org/governance/wgi /sc_country.asp 